\title{
Commentary
}

\section{The Need and Desire for Inclusive Universities: A Perspective from Development Studies}

\author{
Stephen Thompson \\ Participation Inclusion and Social Change Research Cluster, Institute of Development Studies, UK; \\ E-Mail: s.thompson@ids.ac.uk
}

Submitted: 30 January 2021 | Accepted: 10 May 2021 | Published: 21 July 2021

\begin{abstract}
In recent times there has been sustained momentum to address inequalities within university faculties and improve the diversity of students. Also, in response to historical and current social injustices, universities have sought to decolonize curricula. These progressive movements have had particular significance for departments focused on development studies and related subjects because the need to be inclusive is not only the right thing to do from a moral position, but also because to be exclusive is fundamentally challenging to the conceptualization and philosophy of the discipline. Development is a contested term but addressing inequality and working towards social justice are common themes found across most definitions. This commentary provides a critical insight into the importance of inclusive universities as gatekeepers to equitable knowledge production and the development of future professionals. To play their part in addressing the challenges posed by a globalized world, universities need to be proactive in ensuring that they become fully and meaningfully inclusive. While all university departments would benefit from becoming more inclusive, departments focused on development must be the pioneers leading the way, as inclusivity is relevant to the delivery of development studies, as well as emerging as an important discourse within the discipline that continues to evolve. This commentary will explore how and why in an increasingly interconnected global society, the need for universities to leave no one behind, and challenge hegemonic and unequal structures has never been greater.
\end{abstract}

\section{Keywords}

decolonization; development studies; inclusion; universities

\section{Issue}

This commentary is part of the issue "Inclusive Universities in a Globalized World" edited by Liudvika Leišytė (TU Dortmund, Germany), Rosemary Deem (Royal Holloway, UK) and Charikleia Tzanakou (Oxford Brookes University, UK).

(C) 2021 by the author; licensee Cogitatio (Lisbon, Portugal). This commentary is licensed under a Creative Commons Attribution 4.0 International License (CC BY).

\section{Introduction}

The drive towards making universities inclusive has received much attention in recent years. Decolonising curricula and making the recruitment of staff and students fairer are two emerging themes related to inclusion for higher education. The need to decolonize curricula is framed by the ambition to overcome power and take back control of the knowledge that is taught and produced at universities. It is not so much about isolating formally disempowered people and places, but rather it is about reframing knowledge in terms of what is relevant (Katundu, 2019). To achieve decolonization, ways of generating evidence that were previously surprised or ignored must be reappraised and re-socialized. These formally overlooked approaches must be integrated with new approaches relevant to contemporary challenges and aspirations (Nyamnjoh, 2019). Drawing on the ideas of Allen Luke, Janks (2019) argues that decolonizing curricula is about working towards effecting recognitive, redistributive and representative social justice in education.

Universities are often keen to point out how inclusive they have become for branding purposes, yet inequalities in higher education with regards to class, disability, gender, race, and other dimensions continue to persist. 
In many contexts there has been significant advancement in broadening the social base of students in higher education. Despite this, some groups remain marginalized. For example, globally, the enrolment of students with disabilities remains low (Thompson, 2020). Data from 35 low- and middle-income countries indicates that the average university completion rate for students with disabilities is only 4.5 percent, compared to 7.9 percent for those without a disability (Leonard Cheshire, 2018). Research over time has consistently shown that students with low socioeconomic status have fewer opportunities to succeed in higher education compared to their counterparts who have high socioeconomic status (Jury et al., 2017). Discrimination based on race is still rife in higher education (Museus et al., 2015). Law (2017) argues that to begin to address racism in universities and achieve de-racialization and de-colonization, the historic role of universities as producers of racialized knowledge must be acknowledged.

While student bodies are in general becoming more diverse, the teaching workforce, is failing to reform and become inclusive at the same pace (Poloma, 2014). This is despite evidence suggesting that a diverse university faculty can have a positive impact on both educational outcomes (particularly so for students from underrepresented minority backgrounds) and employee performance (Setati et al., 2019; Stout et al., 2018). Carey et al. (2020, p. 535) suggest that "the primary reason for the lack of diversity among faculty is not a lack of desire to hire them, but the accumulation of implicit and institutionalized biases." Gender inequality persists in academia, with patriarchy or hegemonic masculinity continuing to dominate (David, 2015). A disproportionate number of academic staff are still men (Eddy \& Ward, 2017). Identities can intersect leading to some people experiencing multiple inequalities. For example, in some contexts, a combination of systemic and entrenched racism and sexism may present barriers to the professional development of academics (Davis \& Maldonado, 2015; Setati et al., 2019).

Museus et al. (2015) argue that the university sector acts as a microcosm of society-pervasive inequalities in society will also be pervasive in the tertiary education sector. However, it is also true that if the university labour force is unrepresentative, then the whole knowledge economy will also be unrepresentative (Connell, 2019). For all university departments this is a challenge. For departments that focus on development studies, it is a challenge that threatens to undermine the main philosophical pillars of the discipline.

\section{A Perspective from Development Studies}

There is no universally accepted definition of development. Broadly, development can be used to mean 'good change,' although it is accepted that this is subjective and will depend on what each individual considers as 'good' (Chambers, 1997). Remenyi (2004) regards development as processes that aim to improve standards of living and greater capacity for self-reliance. Sen (1999) argues that development is fundamentally about increasing freedom. This includes removing sources of unfreedom, such as tyranny, oppression, and inequality. Kingsbury (2004, p. 1) describes development as "being concerned with how 'developed countries' can improve their living standards and eliminate absolute poverty." However, the UK-based Development Studies Association (2021) clarifies that the historic focus on economically poorer countries in Africa, Asia and Latin America is outdated and that the focus now extends to development issues worldwide, including addressing the global challenge of combatting poverty, injustice, and environmental degradation.

Sachs (2020) described development as the rallying cry of the postcolonial era, which facilitated the West to wield power over the world in the name of progress. More recently, development has become about survival rather than progress. This new era was ushered in with the introduction of the Sustainable Development Goals (SDGs), which are designed to guarantee the minimum level of human rights and environmental conditions (Sachs, 2020). The SDGs were introduced by the United Nations as a developmental blueprint for achieving a sustainable future for all. The SDG agenda is built on the notion of universality, where universal principles, values and standards, are applicable in all contexts and circumstances and at all times. By moving beyond outmoded understandings of development and by adopting a universal approach to development, the SDGs promised to leave no one behind (UN, 2015).

While development is a contested and dynamic term, prominent themes across definitions include addressing inequality and working towards social justice. It therefore would be paradoxical for a university department that specializes in development not to pursue the highest possible standards of inclusivity. If an institution of development studies is not working to improve its inclusivity, it will be not only failing to do the right thing to do from a moral position but diminishing understandings of the discipline itself. Excluding anyone from study or research, but in particular groups or individuals who are regularly 'left behind' by society, is fundamentally challenging to the philosophy of development.

The main roles of a university are research and teaching. As institutions, universities are therefore important gatekeepers to both knowledge production and the education of future professionals. Universities have historically been exclusive by design, with entry linked to a particular type of academic achievement, which is heavily influenced by deep structural, social inequities and inequalities. Such unequal power relations must be challenged if inclusive universities are to be nurtured. If a student or faculty member manages to overcome unfair barriers to entry, the next stumbling block may be the university environment. Invisible barriers may keep people with certain characteristics or identities on 
the outside. The UK Development Studies Association (2021) argues that decolonizing curricula alone is not enough. Institutions, procedures, practices, as well as default ways of thinking and acting must be reformed.

Teachers are important role models for students. If faculties are not inclusive, then this may impact on how students with particular identities and characteristics experience higher education. If a student cannot find a teacher who looks, talks or thinks like them, they may start to question if they belong in that space. To ensure no one feels unwelcome or unwanted, key university gatekeepers and students must collaborate. Inclusivity can bolster academic success but can also facilitate students to feel heard and supported (Bessaha et al., 2020). A degree is an essential specification for most teaching jobs, so if students with certain identities or characteristics are excluded from tertiary education, then they will never be able to become academic staff, continuing the cycle of exclusion. After graduating, many development students go on to work in the development industry for governments, non-government organizations, and funders, among others. If development degree programs are not inclusive, a bottleneck is created, restricting the whole industry from diversity and a plurality of experience and background. Such barriers can act to propagate elitism, reinforce hegemony, and maintain structural inequalities.

In terms of knowledge production, developmentfocused research undertaken by universities is essential if the pressing challenges posed by a globalized world are to be addressed. Undertaking this research in an ethical way is well understood and considered essential as part of any standard evidence generation process. However, undertaking research in an inclusive way often requires specific positive action to ensure marginalization is neither created nor perpetuated. Researchers must question who is being left behind, whose viewpoint has been excluded, whose reality is being counted (Chambers, 1995). If the university is not inclusive in hiring staff, it is unrealistic to expect the research that is conducted to be fully inclusive. A diverse faculty are more likely to conceptualize research in a more inclusive way.

Connell (2019) argues that a 'good university' is one that aims to deliver social good and actively contributes to building a fairer society. Social justice should therefore underpin both teaching and research, with the least advantaged in society being prioritised. This is of course relevant to all university departments, but particularly relevant to institutes of development studies, as it resonates so strongly with the underpinning philosophies of the discipline.

Nearly 30 years ago in the first edition of The Development Dictionary, Sachs (1992) described the idea of development as being like a ruin in the intellectual landscape due to the persistent delusion, disappointment, failures and crimes associated with it as a concept. However, in the preface to a more recent edition, Sachs (2010) admits that the extent to which development is charged with hopes for redress and self-affirmation was not fully appreciated-and that "the South has emerged as the staunchest defender of development" (Sachs, 2010, p. viii). The desire for dignity, equality and redress can therefore be seen to be entangled with the desire for development. When considering decolonization of development, the complexity of people's desire for development must be considered (Matthews, 2017). Development is subject to a tension between the desire to do good, and the knowledge required to achieve that desire, and Makuwira (2018) argues that if development is to avoid reproductions of power that can result in marginalization, those involved in the discipline must recognise their own ignorance and open themselves up to new realities and understandings. A similar sentiment is displayed by Chambers (2017), who argues that to do better in development, we have to know better.

By taking action to gain a better understanding of how we can improve inclusivity, development focused departments can stabilize the ruin of development as a concept and start working towards returning it to a functioning structure. However, caution is needed as any intervention that is undertaken in a disingenuous way to signal a façade of inclusivity without addressing fundamental challenges, will only be papering over the cracks. Departments that fail to be meaningfully inclusive would further contribute to that conceptual decay and the very philosophy of development starts to crumble again. Unless the way that higher education (and development studies) is conceived, designed, delivered, and evaluated is fundamentally revisited, interventions undertaken in the name of inclusion may just lead to greater disillusionment and exclusion for those who are already oppressed.

\section{Conclusion}

Much progress has been made to make universities more inclusive, but there is still work to be done. Advancement towards inclusivity has not been uniform across disciplines and varies depending on context and culture. Addressing intersecting marginality continues to be a challenge for those left furthest behind.

While all university departments should be aiming to be fully inclusive, this ambition is particularly pertinent for those that focus on development studies. If development is regarded as good change, then the nuance of what this means is likely to vary according to each individual (Chambers, 1997). Chambers (1997, p. 1751) suggests that "what we should seek, then, is not consensus but pluralism, not a conclusion but a process, and not permanence but change in evolving concepts." In a similar way to how development can be regarded as a dynamic, and changeable concept, so too must inclusivity in universities evolve and adapt. The extent and speed to which inclusivity can be achieved will depend on the circumstances in any country, institute or discipline. In some contexts, the most effective interventions to 
improve inclusivity may involve diversifying the student body. In others, universities may pursue inclusive faculty recruitment, decolonizing the curriculum, or developing inclusive pedagogy and evaluation approaches. As well as teaching, evidence generation must become fully inclusive. The success of these initiatives will be informed and depend on the commitment, vision, and resources available to make it happen.

To progress we must actively seek to be more inclusive through self-criticism, reflection, and both learning from others and sharing. Reflecting on positionality, it is recognized that this commentary was written from a position of privilege. To develop inclusive universities for a globalized world we must learn from those who have previously been marginalized and engage with those who have been left behind. As Freire (1970, p. 84) wrote regarding the education of those who had formally been oppressed: "Looking at the past must only be a means of understanding more clearly what and who they are so that they can more wisely build the future."

\section{Acknowledgments}

Thanks to Doctor Peter Taylor, the Director of Research at the Institute of Development Studies, for reviewing a draft of this commentary.

\section{Conflict of Interests}

The author declares no conflict of interests.

\section{References}

Bessaha, M., Reed, R., Donlon, A., Mathews, W., Bell, A., \& Merolla, D. (2020). Creating a more inclusive environment for students with disabilities: Findings from participatory action research. Disability Studies Quarterly, 40(3). http://dx.doi.org/10.18061/dsq. v40i3.7094

Carey, J., Carman, K., Clayton, K., Horiuchi, Y., Htun, M., \& Ortiz, B. (2020). Who wants to hire a more diverse faculty? A conjoint analysis of faculty and student preferences for gender and racial/ethnic diversity. Politics, Groups, and Identities, 8(3), 535-553.

Chambers, R. (1995). Poverty and livelihoods: Whose reality counts? Environment and urbanization, 7(1), 173-204.

Chambers, R. (1997). Responsible well-being: A personal agenda for development. World Development, 25(11), 1743-1754.

Chambers, R. (2017). Can we know better? Reflections for development. Practical Action Publishing.

Connell, R. (2019). The good university. Zed.

David, M. (2015). Women and gender equality in higher education? Education Sciences, 5(1), 10-25.

Davis, D., \& Maldonado, C. (2015). Shattering the glass ceiling: The leadership development of African American women in higher education. Advancing Women in Leadership Journal, 35, 48-64.

Development Studies Association. (2021). What is development studies? Development Studies Association. https://www.devstud.org.uk/about/what-isdevelopment-studies

Eddy, P. L., \& Ward, K. (2017). Problematizing gender in higher education: Why leaning in isn't enough. In: P. Eddy, K. Ward, \& T. Khwaja (Eds.), Critical approaches to women and gender in higher education. Palgrave Macmillan.

Freire, P. (1970). Pedagogy of the oppressed. Continuum.

Janks, H. (2019). The decolonization of higher education in South Africa: Luke's writing as gift. Curriculum Inquiry, 49(2), 230-241.

Jury, M., Smeding, A., Stephens, N. M., Nelson, J. E., Aelenei, C., \& Darnon, C. (2017). The experience of low-SES students in higher education: Psychological barriers to success \& interventions to reduce social-class inequality. Journal of Social Issues, 73, 23-41.

Katundu, M. (2019). Which road to decolonizing the curricula? Interrogating African higher education futures. Geoforum, 115, 150-152.

Kingsbury, D. (2004). Introduction. In D. Kingsbury, J. Remenyi, J. McKay, \& J. Hunt (Eds.), Key issues in development (pp. 1-21). Palgrave Macmillan.

Law, I. (2017). Building the anti-racist university, action and new agendas. Race Ethnicity and Education, 20(3), 332-343.

Leonard Cheshire. (2018). Disability data review: A collation and analysis of disability data from 40 countries. Leonard Cheshire.

Makuwira, J. (2018). Power and development in practice: NGOs and the development agenda setting. Development in Practice, 28(3), 422-431.

Matthews, S. (2017). Colonised minds? Postdevelopment theory and the desirability of development in Africa. Third World Quarterly, 38(12), 2650-2663.

Museus, S. D., Ledesma, M. C., \& Parker, T. L. (2015). Racism and racial equity in higher education. ASHE Higher Education Report, 42, 1-112.

Nyamnjoh, F. (2019). Decolonizing the university in Africa. In W. R. Thompson (Ed.), Oxford research encyclopedia of politics. https://doi.org/10.1093/ acrefore/9780190228637.013.717

Poloma, A. (2014). Why teaching faculty diversity (still) matters. Peabody Journal of Education, 89(3), 336-346.

Remenyi, J. (2004). What is development? In D. Kingsbury, J. Remenyi, J. McKay, \& J. Hunt (Eds.), Key issues in development (pp. 22-44). Palgrave Macmillan.

Sachs, W. (Ed.). (1992). The development dictionary: A guide to knowledge as power (1st ed.). Zed Books.

Sachs, W. (Ed.). (2010). The development dictionary: A guide to knowledge as power (2nd ed.). Zed Books.

Sachs, W. (2020, February 27). The age of development: An obituary. New Internationalist. https:// 
newint.org/features/2019/12/09/long-read-age-

development-obituary

Sen, A. (1999). Development as freedom. Oxford University Press.

Setati, S., Zhuwao, S., Ngirande, H., \& Ndlovu, W. (2019). Gender diversity, ethnic diversity and employee performance in a South African higher education institution. South African Journal of Human Resource Management, 17(1), 1-8.
Stout, R., Archie, C., Cross, D., \& Carman, C. (2018). The relationship between faculty diversity and graduation rates in higher education. Intercultural Education, 29(3), 399-417.

Thompson, S. (2020). Developing disability-inclusive higher education systems. International Higher Education, 100, 11-12.

UN. (2015). Transforming our world: The 2030 agenda for sustainable development. United Nations.

\section{About the Author}

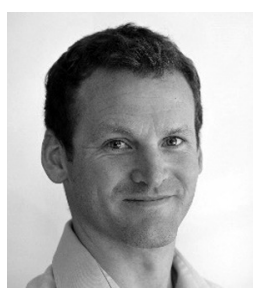

Stephen Thompson (PhD) is a Social Scientist who has worked for over fifteen years in international development for research institutes and non-government organisations in both Europe and Africa. He is currently a Post-Doctoral Research Fellow in the "Participation, Inclusion, and Social Change" research cluster at the Institute of Development Studies, University of Sussex. His research interests are disability inclusion, sustainable development, and participatory methodologies. He has a particular interest in higher education, inequality, and social justice. 